BISEI: Jurnal Bisnis dan Ekonomi Islam

Volume 06, Nomor 01, Juni 2021

Terakreditasi Nomor SK: B/4130/E5/.2.1/2019

E-ISSN 2541-2671. Hal. 63-73

\title{
NILAI-NILAI ETIKA BISNIS ISLAM SEBAGAI PONDASI PENGEMBANGAN PT. BANK SYARIAH INDONESIA (Perspektif Hukum Islam dan Global Compact)
}

\author{
Naily El Muna ${ }^{1 *}$ \\ Jurusan Ekonomi Syariah, Fakultas Agama Islam Universitas KH. A. Wahab \\ Hasbullah. \\ Jalan Raya Garuda No.09 Tambakrejo Jombang, 61419, Indonesia
}

\begin{abstract}
This study portrays the efforts of Islamic banking to motivate employees in familiarizing the values of Islamic business ethics. The development of Islamic banking has experienced significant growth. A survey by the financial services authority (OJK) stated that the assets of the Islamic banking industry increased 14 times from Rp. 21.5 trillion in 2005 to Rp. 296, 2 trillion in 2015. Islamic Banking I should implement the values of Islamic Business Ethics (EBI) in accordance with Islamic law. These values are divine values, balance (justice), freedom and responsibility. Researchers used a qualitative approach to normative juridical case studies. The findings and theories were built using snowball sampling, which is the process of searching for data from and according to needs. Data collection was carried out by: interviews, observation, and documentation. Data analysis used: data reduction, data presentation, drawing conclusions. The results of this study include: (1) EBI habituation process: (a) As a spirit, (b) There is an emotional bond, the equality of managers, and users of customer funds,

(c) The principle of the object is halal, mutual acceptance, needs, habits, and existential,

(d) Being accounted for in a balanced manner in the form of scope of work, (2) The process of familiarizing EBI with employees in accordance with Islamic law.
\end{abstract}

Keywords: Islamic business ethical values, habituation, Islamic law

Paper type: Research paper

*Corresponding author: elmunanaily09@ gmail.com

Received: 13 Mei 2021; Accepted: 17 Juni 2021; Published: 30 Juni 2021

Cite this document: Naily El Muna. (2021). Nilai-Nilai Etika Bisnis Islam Sebagai Pondasi Pengembangan Bank Syariah Indonesia (Perspektif Hukum Islam dan Global Compact). BISEI: Jurnal Bisnis dan Ekonomi Islam, 6 (1), 63-73

Copyright $\odot$ C 2020, BISEI: Jurnal Bisnis dan Ekonomi Islam http://ejournal.unhasy.ac.id/index.php/bisei 
Abstrak: Penelitian ini memotret upaya Bank Syariah Indonesia memotivasi pegawai dalam pembiasaan nilai-nilai etika bisnis Islam. Perkembangan Bank Syariah Indonesiamengalami pertumbuhan signifikan. Survey otoritas jasa keuangan (OJK) menyebutkan, aset industri Bank Syariah Indonesiameningkat 14 kali dari Rp. 21,5 triliun tahun 2005 menjadi Rp. 296, 2 triliun tahun 2015. Bank Syariah Indonesiasayogyanya melaksanakan nilai-nilai Etika Bisnis Islam (EBI) sesuai hukum Islam. Nilai tersebut yaitu nilai ketuhanan, keseimbangan (keadilan), kebebasan dan tanggung jawab. Peneliti menggunakan pendekatan kualitatif studi kasus yuridis normatif. Temuan dan teori dibangun dengan snowball sampling, yaitu proses pencarian data dari dan disesuaikan kebutuhan. Pengumpulan data dilaksanakan dengan: Wawancara, observasi, dan dokumentasi. Analisis data digunakan: reduksi data, penyajian data, penarikan kesimpulan. Hasil penelitian ini meliputi: (1) Proses pembiasaan EBI: (a) Sebagai ruh, (b) Adanya ikatan emosional, kesederajatan pengelola, dan pengguna dana nasabah, (c) Prinsip objeknya halal saling ridho, kebutuhan, kebiasaan, dan eksistensial, (d) Dipertanggungjawabkan seimbang dalam bentuk ruang lingkup pekerjaan, (2) Proses pembiasaan EBI pada pegawai sesuai dengan hukum Islam.

Kata kunci: Nilai etika Bisnis Islam, pembiasaan, hukum Islam

\section{Pendahuluan}

Perkembangan Bank Syariah Indonesiamengalami pertumbuhan yang signifikan, bahkan menjadi tren di masyarakat. Di masa pandemi, perbankan syariah di Indonesia menunjukkan tren perkembangan positif. Bank Syariah Indonesiatumbuh positif 9,22 persen atau Rp 545,39 triliun. "Walau di tengah pandemi Covid-19, aset perbankan syariah Indonesia pada semester I-2020 mencapai Rp 545,39 triliun, tumbuh 9,22 persen," tulis akun Instagram @ojkindonesia, Jakarta, Rabu (23/9). Dana Pihak Ketiga (DPK) Bank Syariah Indonesiajuga mengalami peningkatan di semester ini. Otoritas Jasa Keuangan (OJK) mencatat pertumbuhan DPK Bank Syariah Indonesiayakni Rp 430,209 triliun, meningkat dibandingkan tahun 2019 yakni Rp 425,29 triliun (Liputan6, 2020).

Sri Mulyani berpendapat, "Indonesia merupakan sebuah negara yang memiliki kebhinekaan namun mayoritas masyarakatnya adalah muslim. Oleh karena itu, Indonesia memiliki kekuatan yang luar biasa untuk memberikan jawaban mengenai relevansi nilai-nilai Islam di dalam kehidupan dunia dan di 
dalam negeri.(Liputan6, 2020.)". Mempertimbangkan kedua realitas tersebut, idealnya pegawai Bank Syariah Indonesiayang sehari-harinya bergelut pada operasi bisnis syariah pada tataran mengerti dan paham akan hakikat nilai-nilai etika bisnis Islam.

Etika merupakan studi sistematis tentang tabiat konsep nilai, baik, buruk, harus, benar, salah, dsb. Etika bisnis dapat berarti pemikiran atau refleksi tentang moralitas dalam ekonomi dan bisnis (Faisal, 2006). Etika adalah komitmen seseorang untuk bersikap berulang-ulang tanpa berpikir Panjang (Khalaf, 1997). Upaya Bank Syariah Indonesiadalam memotivasi pegawai menerapkan nilai-nilai etika bisnis Islam adalah hal yang penting. Mengingat tidak semua pegawai berasal dari pendidikan berbasis Islam.

Hukum Islam menurut Abdul Wahab khalaf sebagai perintah (doktrin) dari Allah Swt., yang berkaitan dengan perbuatan orang-orang yang sudah mukallaf (orang yang sudah dikenai beban syariat), dalam bentuk perintah (mengerjakan atau meninggalkan suatu perbuatan), perizinan (boleh memilih), atau penetapan (Khalaf, 2003). Tujuan pemberlakuan hukum Islam adalah aturan yang dijalankan untuk mencapai kebahagiaan hidup manusia di dunia dan di akhirat dengan mengambil semua manfaat dan mencegah bahaya yang tidak berguna bagi kehidupan.

Etika bisnis menurut hukum Islam harus dibangun dan dilandasi oleh nilainilai kesatuan (unity), keseimbangan/keadilan (equilibrium), kehendak bebas/ikhtiar (free will), pertanggung jawaban (responsibility) dan kebenaran (truth), kebajikan (wisdom) dan kejujuran (fair) (Beekun, 2010). komitmen seseorang untuk membiasakan keempat nilai etika bisnis Islam menjadi factor pendorong terwujudnya kinerja yang baik.

Nilai ketuhanan, Nilai ketuhanan memerintahkan agar kita mengingat keagungan Allah SWT (Al Qur'an, 2015). Nilai tauhid ini, dalam melaksanakan hukum Islam bernilai ibadah. Nilai keseimbangan (keadilan) mempunyai makna persamaan dalam kesempatan dan sarana. Nilai kebebasan dimaksudkan bahwa seseorang tidak ada paksaan dalam melakukan kegiatan yang dia pilih, Bebas untuk berinisiatif, dan berkreasi dalam bekerja. Elemen ini dapat membimbing 
seseorang bekerja lebih luwes dan professional. Nilai tanggung jawab, seseorang yang sudah mempunyai pemahaman akan nilai ini akan mempunyai komitmen yang tinggi untuk terus mengembangkan usaha yang digelutinya. Keempat nilai etika bisnis Islam tersebut harus benar-benar menjadi ruh para pegawai Bank Syariah Indonesia. Dalam proses penjiwaan ini, para pegawai harus mendapat dukungan dari peraturan-peraturan yang berlaku, jajaran direksi, serta sikap nasabah.

Perbankan syariah pada umumnya mengakui bahwa kelangsungan usaha mereka terkait dengan kelangsungan masyarakat yang lebih luas. Kebijakan dan praktek manajemen ditentukan di berbagai tingkat dan dapat menerima panduan dari berbagai sumber, diantara prinsip global compact. Global Compact mengarahkan perusahaan-perusahaan untuk mengintegrasikan ke dalam praktek mereka sehari-hari serta mempromosikan ke sepuluh prinsip yang sudah lama diakui oleh masyarakat internasional sebagai prinsip-prinsip yang universal (Organisasi Perburuhan Internasional, 2009). Perusahaan yang berkomitmen untuk memperbaiki praktek bisnis di empat bidang yang dapat membantu menciptakan globalisasi yang lebih adil dan lebih inklusif: hak asasi manusia, peraturan ketenagakerjaan, perlindungan lingkungan serta upaya untuk memerangi korupsi.

PT Bank Syariah Indonesia Tbk (BSI) mencatatkan Laba Bersih Rp742 miliar pada triwulan 1 2021, naik 12.85\% dibandingkan periode sama tahun 2020 sebesar Rp657 miliar. Kenaikan kinerja triwulan 12021 didorong oleh kenaikan pendapatan margin dan bagi hasil sampai triwulan 12021 sebesar 5,16\% (Berita Media, 2021). Melihat adanya perkembangan positif Bank Syariah Indonesia di tengah pandemic, sudah seharusnya jika Bank Syariah Indonesia lebih memantabkan pegawainya untuk membiasakan etika bisnis Islam. Dan diperlukan adanya penelitian nilai-nilai etika bisnis Islam yang bisa diterapkan di perbankan syariah. Untuk itu peneliti melaksanakan kajian normatif mengenai nilai-nilai etika bisnis Islam dalam hukum Islam. 


\section{Metode Penelitian}

Peneliti menggunakan pendekatan normatif dengan analisis yuridis normatif. Temuan dan teori dibangun dengan menganalisis hukum Islam dan prinsip global compact. Data yang diperoleh dianalisis disajikan dalam penulisan yang sistematis dengan harapan dapat memberikan suatu jawaban atas permasalahan yang bersifat umum terhadap permasalahan konkret yang dihadapi (Ibrahim, 2012). Penelitian ini dianalisis berdasarkan bahan hukum (Johan, 2008) yang ada digunakan untuk melihat apakah pembiasaan etika bisnis Islam ini sudah benar-benar diterapkan dilihat dari hukum itu sendiri. Informannya adalah perwakilan dari pegawai Bank Syariah Indonesia cabang Jombang. Analisis data juga didiskusikan dengan kajian hukum Islam para pakar. Kredibelitasnya diuji melalui intrepretasi kajian hukum Islam dari ilmuwan muslim dan prinsip global compact.

\section{Hasil dan Pembahasan}

Penelitian ini diintrepretasikan melalui analisis normativ nilai-nilai etika bisnis Islam dalam Hukum Islam dan global compact sebagai berikut :

Etika merupakan suatu keadaan yang tertanam dalam jiwa berupa keinginan yang sangat kuat, kemudian melahirkan suatu tindakan yang berulang-ulang tanpa berpikir panjang (spontan) (Beekun, 2010.). Menurut Baron and David "Business ethics is the application of ethics principles to issues that arise in the conduct of business (Baron and P David, 2003). Etika pegawai dalam organisasi akan dibentuk melalui faktor-faktor yang dipaparkan dalam gambar di bawah ini:

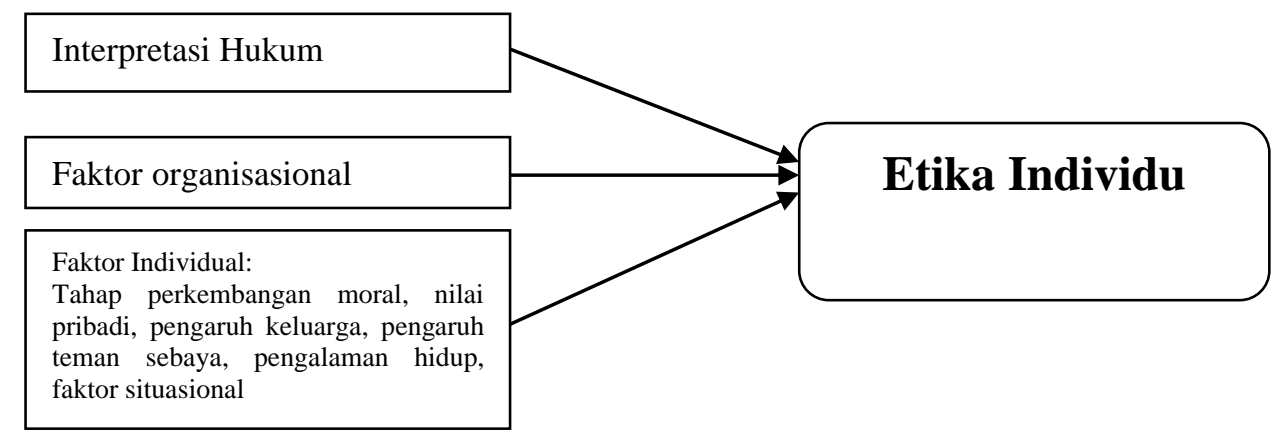

Gambar 1: Determinan Etika Individu(Beekun, n.d.) 
Interpretasi etika bisnis masyarakat berbasis hukum didasarkan pada nilai-nilai dan standar kontemporer. Dalam hal ini PT. Bank Syariah Indonesia sudah menerapkan Izin Lingkungan sesuai dengan global compact, antara lain berkenaan dengan : 1) bisnis semestinya mendukung dan menghargai proteksi HAM yang telah dideklarasikan secara internasional; 2) memastikan bahwa tidak terlibat dalam eksploitasi HAM; 3) bisnis semestinya mendukung kebebasan berserikat dan menghargai hak untuk berunding secara kolektif; 4) penghapusan semua bentuk kerja paksa; 5) penghentian secara efektif keterlibatan pekerja anak; 6) penghapusan diskriminasi dalam kesempatan dan jenis pekerjaan; 7) bisnis semestinya mendukung pendekatan pembatasan pelanggaran lingkungan; 8) mengambil inisiatif untuk lebih bertanggung-jawab terhadap lingkungan; 9) mendukung pengembangan dan distribusi teknologi yang akrab lingkungan; 10) anti korupsi (Organisasi Perburuhan Internasional, 2009).

Penerapan global compact PT. Bank Syariah Indonesia akan selalu menguntungkan perusahaan baik untuk jangka menengah maupun jangka panjang karena: 1) Akan dapat mengurangi biaya akibat dicegahnya kemungkinan terjadinya friksi baik intern perusahaan maupun dengan eksternal. 2) Akan dapat meningkatkan motivasi pekerja. 3) Akan melindungi prinsip kebebasan ber-niaga. 4) Akan meningkatkan keunggulan bersaing. Dan sebaliknya tindakan yang tidak etis, bagi perusahaan akan menimbulkan tindakan negatif dari konsumen dan masyarakat misalnya; melalui gerakan pemboikotan, larangan beredar, larangan beroperasi, dan tindakan lain yang dapat merugikan perusahaan.

Sementara dalam masyarakat Islam, nilai-nilai dan standar ini dituntun oleh ajaran Syariah dan kumpulan fatwa fiqih. Faktor organisasi juga dapat memberikan pengaruh terhadap cara berperilaku anggotanya. Salah satu aspek kunci pengaruh organisasional adalah tingkat komitmen pemimpin organisasi terhadap nilai-nilai etis. Komitmen ini dapat dikomunikasikan melalui kode etik, kebijakan organisasi, pidato-pidato, publikasi, dll (Beekun, 2010.). Beliau berpendapat, etika bisnis Islam mempunyai nilai-nilai moral yang mengandung motivasi untuk rajin bekerja. Nilai-nilai tersebut dalam table 1 yaitu (Beekun, 2010.): 


\begin{tabular}{|l|l|}
\hline Nilai keesaan & $\begin{array}{l}\text { Berhubungan dengan konsep Tauhid, berbagai aspek } \\
\text { dalam kehidupan manusia yakni politik, ekonomi, } \\
\text { sosial dan keaagamaan membentuk satu kesatuan } \\
\text { homogen, yang bersifat konsisten dari dalam dan } \\
\text { integrasi dengan alam semesta secara luas. Ini adalah } \\
\text { dimensi vertikal Islam. }\end{array}$ \\
\hline Nilai keseimbangan & $\begin{array}{l}\text { Berhubungan dengan konsep keesaan adalah } \\
\text { keseimbangan diantara berbagai kehidupan manusia } \\
\text { seperti yang disebutkan di atas untuk mencapai aturan } \\
\text { sosial yang terbaik. Rasa keseimbangan ini diperoleh } \\
\text { melalui tujuan yang sadar. Ini adalah dimensi } \\
\text { horizontal Islam. }\end{array}$ \\
\hline Nilai kehendak bebas & $\begin{array}{l}\text { Kemampuan manusia untuk bertindak tanpa tekanan } \\
\text { eksternal dalam ukuran ciptaan Allah SWT dan } \\
\text { sebagai khalifah Allah di muka bumi. }\end{array}$ \\
\hline Nilai tanggung jawab & $\begin{array}{l}\text { Keharusan manusia untuk diperhitungkan semua } \\
\text { tindakannya }\end{array}$ \\
\hline Nilai kebajikan & $\begin{array}{l}\text { Ihsan atau suatu tindakan yang memberi keuntungan } \\
\text { bagi orang lain tanpa ada suatu kewajiban tertentu. }\end{array}$ \\
\hline
\end{tabular}

Komitmen pimpinan Bank Syariah Indonesiauntuk membiasakan berperilaku etis tercermin dalam kode etik, tata tertib, pembinaan rutin pegawai dan reward loyalitas pegawai. Yang ke semua pembiasaan nilai etika bisnis Islam mampu terdeskripsikan dalam :

\section{Nilai Ketuhanan}

Nilai ketuhanan pada pegawai Bank Syariah Indonesia tercermin dalam paradigma transaksinya, yang spesifik diatur dalam Kerangka Dasar Penyusunan dan Penyajian Laporan Keuangan Syariah (KDPPLK Syariah). Sebagaimana dijelaskan dalam Bagan 1 di bawah ini; 


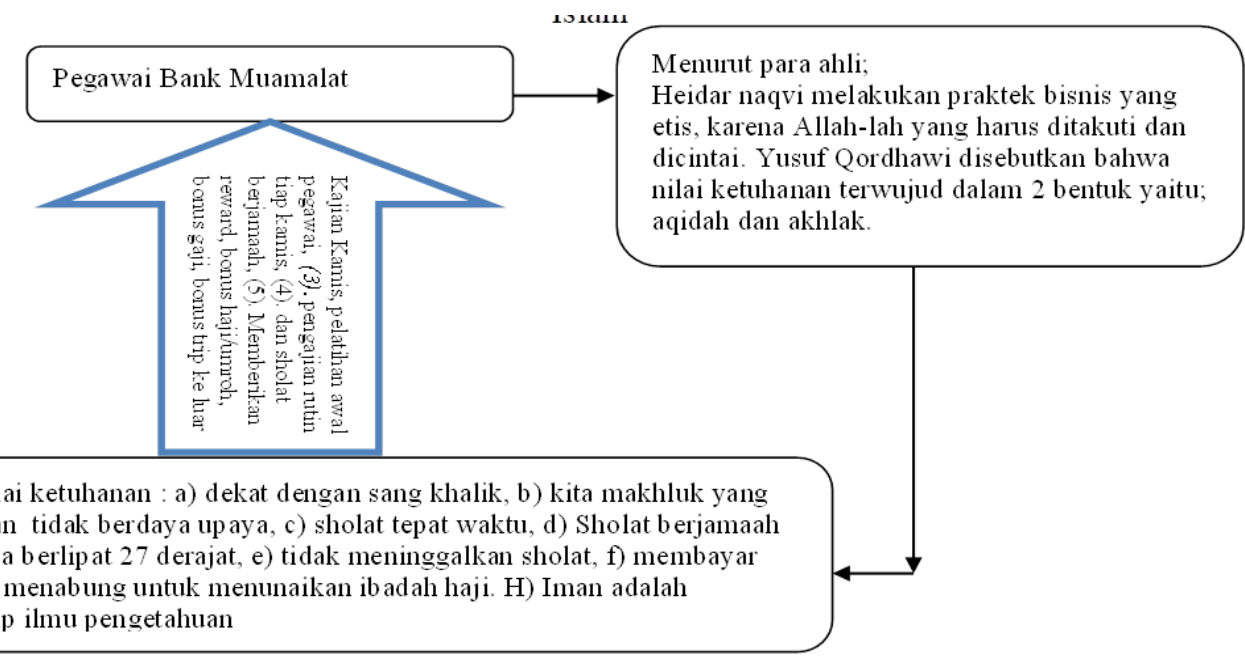

Nilai keTuhanan hanya ada di Bank Syariah Indonesia, berasal dari keyakinan seseorang. Nilai yang sangat dibutuhkan ketika mengimplementasikan nilai keseimbangan, kebebasan, dan tanggung jawab. Untuk itu setiap pegawai harus melatih dan membangun nilai keTuhanan di dalam diri mereka.

Di Perbankan syariah, proses pembiasaan nilai ke-Tuhanan berawal dari motto Islamic, modern, profesional. Adanya kebijakan yang sesuai dengan aqidah Islam yaitu: adanya pelatihan awal menjadi pegawai, spiritual kamis, waktu untuk sholat berjamaah, kesadaran untuk mengeluarkan zakat, dan reward haji/umroh untuk pegawai. Setelah memahami kebijakan Bank Syariah Indonesia, para pegawai senantiasa mengerjakan sholat di awal waktu istirahat, mengeluarkan zakat dengan suka rela, dan menunaikan ibadah haji.

Dari uraian di atas dapat disimpulkan bahwa: a) Pegawai Bank Syariah Indonesia tidak mengalami kesulitan dalam menerapkan nilai ketuhanan berdasarkan kompilasi hukum ekonomi syariah dan UU No. 21/2008, terlebih hal itu juga selaras dengan pemikiran para ahli. Bank Syariah Indonesia sudah membuat indikator yang menjembatani pelaksanaan nilai ketuhanan tersebut. yaitu: a) Nilai Ketuhanan merupakan ketentuan hukum Islam yang berisi perintah dan larangan, b) Prinsip syariah yang berlaku kegiatan muamalah (transaksi syariah) mengikat secara hukum bagi semua pelaku muamalah. c) Nilai ketuhanan tercermin dalam paradigma transaksinya, yang secara 
spesifik telah diatur dalam Kerangka Dasar Penyusunan dan Penyajian Laporan Keuangan Syariah (KDPPLK Syariah), d) Nilai ketuhanan merupakan norma dan etika yang berisi nilai-nilai moral dalam interaksi agar hubungan tersebut menjadi saling menguntungkan, sinergis dan harmonis, e) mengingatkan bahwa kita makhluk yang lemah dan tidak berdaya upaya, f) sholat tepat waktu, g) tidak meninggalkan sholat, h) membayar zakat, i) menabung untuk menunaikan ibadah haji, j) reward haji/umroh. k) Iman adalah pelengkap ilmu pengetahuan.

\section{Nilai Keseimbangan.}

Adalah nilai yang tidak berat sebelah atau segala sesuatu sesuai dengan proporsi. Pembiasaan nilai keseimbangan berkaitan dengan proses transaksi/akad, ada beberapa statement mengenai hal itu; yaitu; adalah wujud dari keterikatan dua pihak (nasabah dan Bank) seperti saudara, nilai keseimbangan berkaitan dengan penghitungan debit dan kredit, tidak mengandung unsur riba, gharar dan maisir. Pegawai Bank tidak mengalami kesulitan ketika menginternalisasi nilai keseimbangan. Internalisasi nilai Keseimbangan adalah nilai yang sangat berhubungan dengan tata cara hubungan sosial, adanya ikatan kesamaan emosional, prinsip kesedrajatan dan prinsip ketentraman antara pemilik, pengelola, dan pengguna dana. BSI membuat indikator untuk menjembatani pelaksanaan nilai tersebut. Adapun proses pembiasaan nilai keseimbangan dapat dijelaskan dalam gambar 2 : 


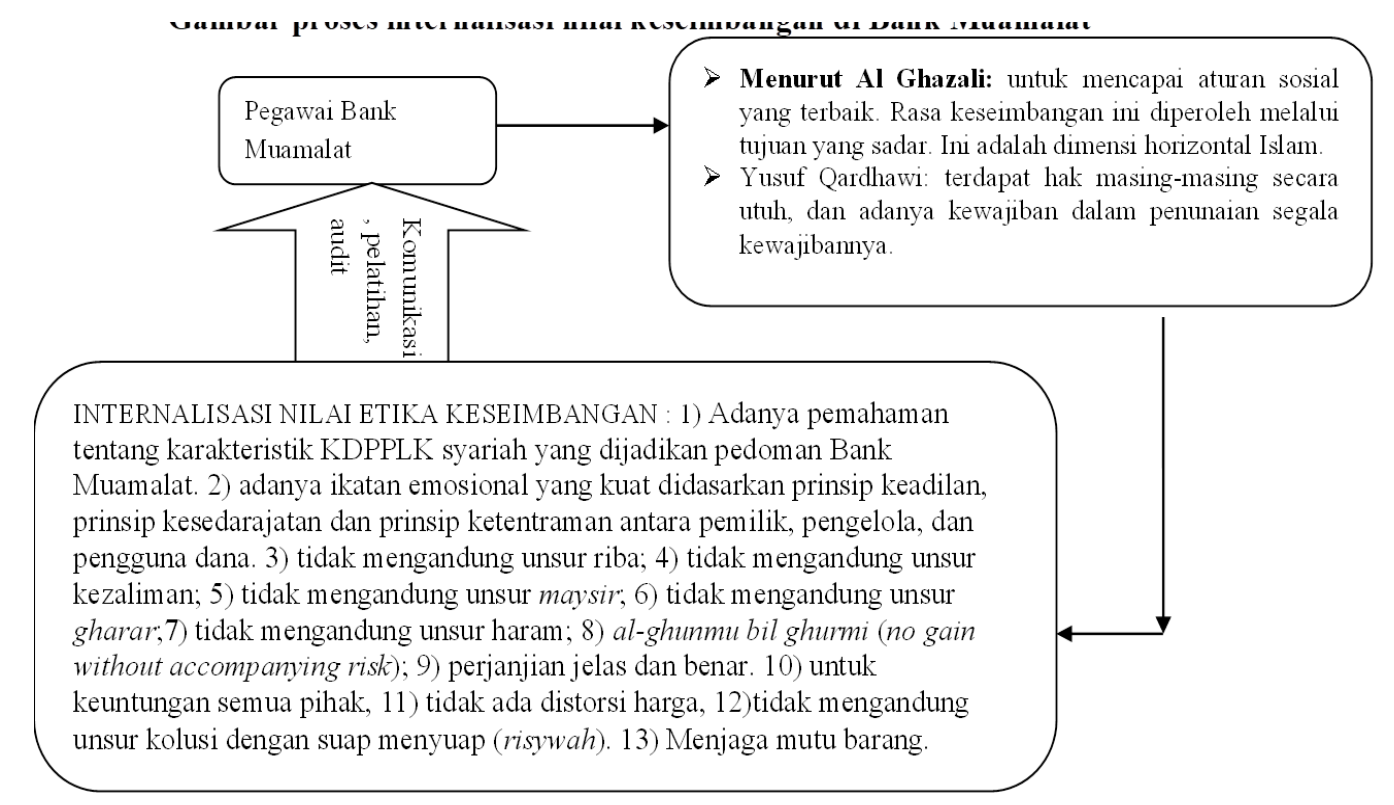

3. NILAI KEBEBASAN

Kebebasan di dalam kamus besar Bahasa Indonesia dikandung maksud tidak terikat atau terbatas oleh aturan. Nilai kebebasan bertransaksi diakui sepanjang objeknya halal dan baik. Perilaku pegawai Bank syariah harus memperhatikan perilaku nasabah/perilaku calon nasabah. Selain itu, pegawai tidak hanya memperhatikan perilakunya untuk menarik nasabah/calon nasabah akan tetapi pegawai juga harus memiliki kemurahan hati kepada nasabah sebagai contoh dalam transaksi pembiayaan dengan memberikan keringanan apabila nasabah belum bisa membayar. Kebebasan juga diartikan; kebebasan dalam bertransaksi, kebebasan dalam berproduksi, kebebasan dalam memilih, membatalkan transaksi, dll. Proses pembiasaan nilai kebebasan dalam perspektif hukum Islam sebagaimana dalam gambar di bawah ini: 
Gambar

Proses Internalisasi nilai kebebasan dalam perspektif hukum Islam

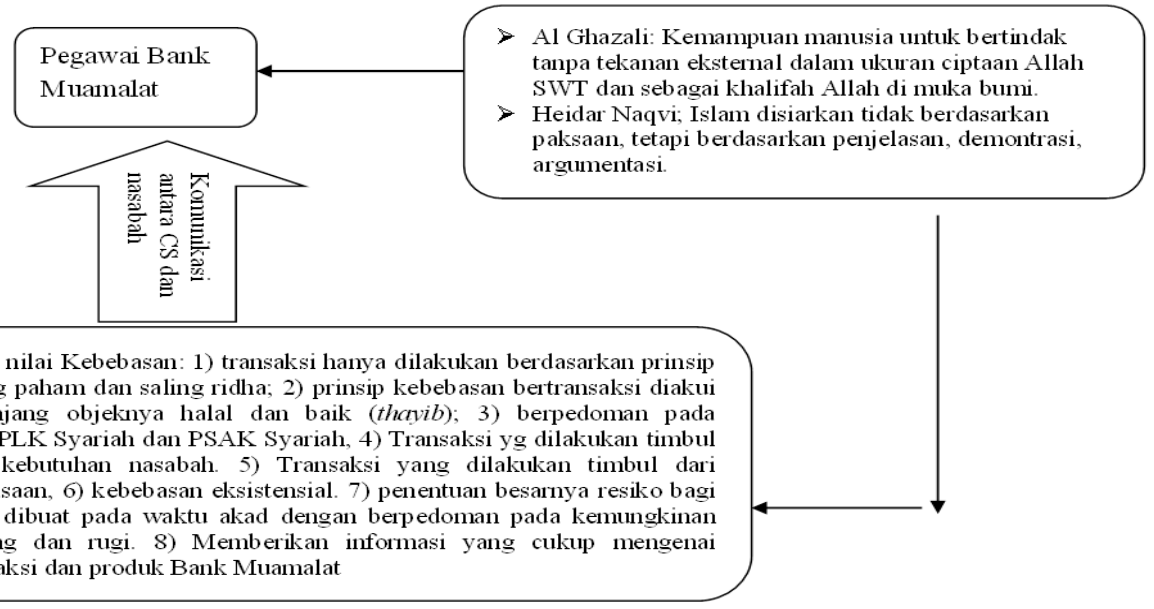

\section{NILAI TANGGUNG JAWAB}

Tanggung jawab dikandung maksud penyelesaian tugas sesuai target perbankan. "Prinsip pertanggung jawaban; selalu berkaitan dengan konsep amanah. Implikasi dalam bisnis dan pegawai adalah individu yang terlibat dalam praktik bisnis harus selalu melakukan pertanggung jawaban atas apa yang telah diamanahkan dan yang diperbuat kepada pihak- pihak yang terkait pada dirinya,

Gambar Proses Internalisasi Nilai Tanggung Jawab

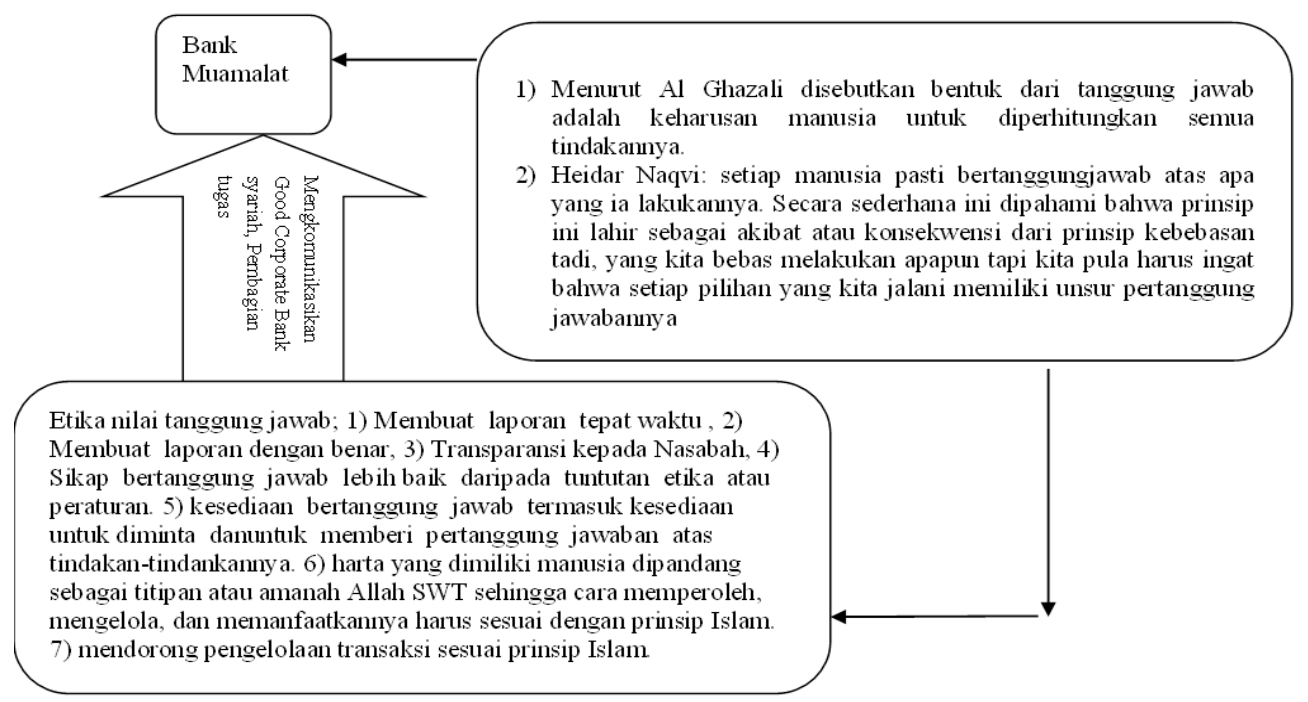

Dari uraian di atas nilai tanggung jawab Islam adalah pertanggung jawaban yang seimbang dalam segala bentuk dan ruang lingkupnya. 
Tanggung jawab perbuatan kepada Allah SWT, tanggung jawab dalam bentuk laporan kepada atasan pegawai, dan tanggung jawab dalam bentuk catatan transaksi kepada nasabah. Nilai tanggung jawab bersumber dari intuisi pegawai Bank syariah Indonesia, menjadi nilai yang membangun untuk memberikan informasi yang berkualitas, dan mengantarkannya menjadi manusia yang dapat dipercaya. Sesuai dengan tujuan dari nilai tanggung jawab, bahwa pegawai Bank Syariah Indonesia bekerja tidak hanya untuk memenuhi kebutuhannya. Akan tetapi juga mempertanggung jawabkan hasil kerjanya kepada Allah SWT, kepada nasabah dan juga atasannya.

\section{Penutup}

Dari pemaparan di atas dapat diambil kesimpulan: Nilai etika bisnis Islam pada pegawai sudah sesuai dengan hukum Islam dan global compact. Nilai-nilai yang terkandung tersebut adalah sebagai (1). ruh untuk melakukan aktivitas perbankan, (2). adanya ikatan emosional, kesederajatan, ketentuan pemilik, pengelola dan pengguna dana nasabah), (3). menganut prinsip objenya halal, saling rela/ridho, kebutuhan, kebiasaan, dan eksistensial. (4). pertanggung jawaban yang seimbang dalam segala bentuk dan ruang lingkup pekerjaan.

\section{Referensi}

Al Qur'an. (2015). No Title Surah Ali Imron; 64.

Baron and P David. (2003). Business and its environment-4'hed (P. Hall \& Upper Saddle river (eds.); 1st ed.). Prentice Hall, Upper Saddle river,.

Beekun, R. I. (n.d.). Etika Bisnis Islami. Pustaka Pelajar.

Berita Media. (2021). Bank BSI catat laba. Berita Media. https://www.bankbsi.co.id/news-update/berita/bank-bsi-catat-laba-rp-742miliar-naik-1285-di-triwulan-1-2021

Faisal, B. (2006). Etika Bisnis dalam Islam (Prenada (ed.); 2nd ed.). Prenada.

Ibrahim, J. (2012). Teol \& Metodologi penelitian hukum normatif, (B. Publishing (ed.); 1st ed.). bayumedia publishing.

Johan, B. N. (2008). Metode Penelitian Ilmu Hukum (Nandar Maju (ed.)). Nandar maju.

Khalaf, A. W. (1997). Falsafatul Akhlâq 'inda Ibni Miskawayh, (1st ed.).

Khalaf, A. W. (2003). 'Ilmu Al-Ușūl Al-Fiqh,. In D. Al-Hadīts (Ed.), journal cairo (1st ed., Vol. 1). Dār Al-Hadìts.

Liputan6. (, September). di-tengah-pandemi-perbankan-syariah-tetap-tumbuh- 
positif. Jakarta. https://www.liputan6.com/bisnis/read/4363732/di-tengahpandemi-perbankan-syariah-tetap-tumbuh-positif-922-persen

Organisasi Perburuhan Internasional. (2009). Prinsip-prinsip Ketenagakerjaan Global Compact - Perserikatan Bangsa Bangsa Panduan untuk Dunia Usaha. In ILO (Ed.), 1 (1st ed., p. 40). ILO.

https://www.ilo.org/wcmsp5/groups/public/---asia/---ro-bangkok/---ilojakarta/documents/publication/wcms_126247.pdf

Undang-Undang Nomor 13 Tahun 2003 tentang Ketenagakerjaan 